\title{
TYPES OF VOCALIZATIONS IN SELF-EXPRESSION AND SELF-INQUIRY
}

\begin{abstract}
A.V. ZIRKO
Abstract

The author discusses vocalizations as using non-verbal voice sounds in self-expression and selfinquiry. The purpose of the study was to investigate the experience of self-expression and selfinquiry through vocalizations in the situations of valuing and evaluating. The researcher hypothesized that placing an individual in a safe place for self-expression on the conditions of valuing creates more authentic and genuine feelings, helping to reveal their authentic voice. On the contrary, placing a person under conditions of evaluating and impressiveness leads to a less authentic feeling and sounding. Two groups of participants were separated. The expressive group was created using the condition of valuing. The impressive group was created using the condition of evaluating. Participants in both groups used their voices to express themselves performing research tasks and then filled out the survey applications reflecting the sounder's body, voice, feelings and listener's feelings during the research. The application's indicators were grouped into six factors: "Psychophysiological authenticity", "Psychological authenticity", "Satisfaction", "Vocalization change", "Perceived emotional involvement", and "Perceived satisfaction". The multilinear mixed effect regression models were built to investigate the influence of the research conditions on these factors and their dynamics. The t-test was used to compare the results between the groups. Significant differences were revealed with the factors "Psychophysiological authenticity", "Psychological authenticity", "Satisfaction", and "Perceived satisfaction". They were greater in the expressive group than they were in the impressive group. The indicators of "Perceived satisfaction" were growing.
\end{abstract}

Keywords: vocal psychotherapy, vocalizations, authenticity, inauthenticity, expressiveness, impressiveness.

\section{Introduction}

In the 20th century, scientists from different branches of humanities began researching the use of music and voice for psychotherapy (Austin, 2008; Hiller \& Gardstrom, 2018; Kern \& Tague, 2017; Lewis, 2017; Lindblad, 2016; Monti \& Austin, 2017; Zirko \& Orlov, 2017a). Although there are many vocal practices in self-expression and self-inquiry (Baker, 2015; Stewart \& McAlpin, 2016), little

The article was prepared within the framework of the HSE University Basic Research Program and funded by the Russian Academic Excellence Project "5-100". 
research has been done due to the requirement of strong interdisciplinary skills in this field (Petrushin, 2009). The relevance of this study lies in the integration of the theoretical analysis and results of the empirical study. New vocal methods have been applied, examined, and described. Because there are few investigations into vocal psychotherapy (Markovich \& Tatsumi, 2015; Vaillancourd, Da Costa, Han, \& Lipski, 2018), this study is meant to be exploratory as a first step towards larger empirical investigations.

The purpose of the study was to investigate the experience of self-expression and self-inquiry through vocalizations in situations of valuing and evaluating. Vocalizations are described as expressions of individual experiences with non-verbal voice sounds (Zirko \& Orlov, 2017b) facilitating self-expression, self-inquiry, self-healing, and finding an authentic voice for an individual. The term "authentic vocalizations" was firstly introduced by Sylka Uhlig (2006). The first primary sounds such as a sudden laughter or a scared scream are the most open, authentic, and free voices; they are not influenced by cultural limitations and express a person's inner experience. Inauthentic vocalizations are often limited by cultural norms and do not express a genuine experience (ibid.). Luisa Pascale (2005) classified two types of singing: public and community singing, defining public singing as professional singing on the stage requiring singing skills, and community singing as singing in a company of friends, to reveal the idea that every individual is musically gifted. Public singing is considered impressive, supposing evaluation from a listener. Community singing is expressive, supposing valuing from a listener. Its purpose is to express an individual's inner experience (Orlov, 2015). Community singing is often used in psychotherapy.

The hypothesis of the research was formulated according to the theoretical model of four vocalization types suggested in this study. They create two continuums and four poles: authenticity/inauthenticity and expressiveness/impressiveness. This model strongly correlates with the ability to find an authentic and genuine voice through vocal self-expressions that are expressive vocalizations (Zirko \& Orlov, 2017a; Rogers, 1993). To classify vocalizations, the author proposes a continuum of authentic and inauthentic vocalizations. It stems from the ideas of congruent and incongruent behavior and authenticity and inauthenticity (Babakina, 2016; Rogers, 1993). The continuum of expressive and impressive vocalizations is based on the idea of expressive and impressive arts (Orlov, 2015). Expressive vocalizations express an individual's feelings and impressive vocalizations help a person impress somebody who is listening to them. The individuals who are expressing their experiences with the sounds of their voices will be described as sounders and the individuals who are listening to their self-expression will be described as listeners below.

Next, a wide variety of vocalizations is located on a plain built with two described continuums and four poles (Zirko \& Orlov, 2017b). Authentic and expressive vocalizations express an individual's experience in a situation of valuing. Authentic impressive vocalizations impress a listener, but they do not fully express an individual's true experience. Inauthentic expressive vocalizations distort an individual's inner experience. Inauthentic impressive vocalizations do not impress 
a listener and do not express an individual's experience. Based on this theoretical model, the following hypothesis of the empirical research has been formulated. Expressive vocalizations which individuals use for self-expression and self-inquiry in a situation of valuing receive higher scores of authenticity in comparison to the impressive vocalizations of individuals who are placed into a situation of outer and inner evaluation and are working on the artistic impressiveness and beauty of their voices.

More thorough examination of the continuum of expressiveness/impressiveness lays in the future perspectives of the study. Here the author researched the peculiarities of different types of vocalizations in psychological vocal practices.

\section{Method}

To research this problem the following situations were modeled: a situation of expressiveness and valuing, when the participants could live through their experience and be fully expressive (Melnikova \& Orlov, 2015) and a situation of impressiveness and evaluating, when the participants had to make a specific impression on a listener (Pascale, 2005).

\section{Participants}

There were 42 participants in the study, including 9 men and 33 women. The average age was 35 years old ( $\mathrm{SD}=8.97$, range: $20-57)$. At this age clients typically apply for psychotherapy. The study did not count gender as a factor of selfinquiry. The research was announced on social platforms and at the website of the Doctoral School of Psychology at the National Research University Higher School of Economics. The announcement described the research purpose and procedure, and included the researcher's contacts. Volunteers of the research completed the introductory application and discussed the investigation with the researcher to determine their goals. Each participant chose one goal (self-expression or impression) and worked on it during the research. They joined either the expressive or the impressive group based on their choices. There were 17 people in the impressive group ( 7 men and 10 women) and 25 people in the expressive group ( 2 men and 23 women). The average age in the impressive group was 35 years old $(\mathrm{SD}=9.26$, range: $23-55)$. The average age in the expressive group was 34 years old $(\mathrm{SD}=8.56$, range: 20-57). Next, the participants formed pairs for vocal sessions. Because of time limitations, they were paired up randomly.

\section{Materials}

The introductory form consisted of 9 five-point graded scales and 1 open question for researching voice usage in different situations and conditions. It was used to enable the participants to identify their research goals. They completed this during the first session and provided in-depth responses orally while marking the multiple choices. The main form consisted of 9 five-point scales assessing the process 
and the result of vocalizing. The questions were matched with the criteria of the four types of vocalizations (see Appendix 1). They reflected the individual's body, voice, and feelings. The form for listeners consisted of 9 five-point scales. The listeners gave answers about what they had heard, described the characteristics of the individual's voice, how they were involved in the process of vocalizing and their own feelings (see Appendix 2).

\section{Procedure}

The participants partook in the research in pairs so that each individual could have a listener. Every session had the following order: sharing and warming up exercises (Linklater, Epp, \& Snow, 1976). Next was the first participant's sounding followed by discussion, feedback from the listener and filling out the research forms. Then the participants switched and repeated the same experiment. The sounding time limit was 7 minutes. The participants vocalized during four to twelve 90-minute sessions once a week. The situation of valuing was modeled in the expressive group. The situation of evaluation was modeled in the impressive group.

In the expressive group each participant was given the chance to sound freely, expressing their feelings and experiences. They were encouraged to listen to themselves, and live through their experience with the sounds of their voices. They valued this experience and positively related to it. After this the listener provided the participant who had just vocalized with their unconditional feedback about their vocalizations.

In the impressive group each participant was asked to represent a specific feeling. Several cards with different emotions were handed out. A participant took a card and represented the emotion written on it. The listener guessed which feeling was represented and gave the evaluative feedback on how the participant acted it out. The participants also evaluated their vocalizations during the task and whether they achieved the goal of communicating the emotion on the card.

\section{Results}

To analyze the main quantitative results of the research, 18 scales from the form for the participants who were vocalizing and the form for the participants who were listening, were grouped in 6 factors. These forms will be described as the form for sounders and the form for listeners below. Three factors each were created within the scales from the sounders' and listeners' forms. The scales of the sounder's satisfaction during and after vocalizing were combined in the factor "Satisfaction". The scales of satisfaction during and after vocalizing in the listener's form were combined in the factor "Perceived satisfaction". The correlation between these scales was significant $(r=.685, p<.001)$ for sounding individuals and $(r=.691$, $p<.001$ ) for listening individuals (sounders and listeners, correspondingly). The remaining 14 scales were grouped through exploratory factor analysis separately for the sounders' and listeners' forms. These remaining fourteen scales were most 
optimally grouped in 4 factors, two factors each for sounders and listeners (see Tables 1 and 2).

Each of the final six factors was given the following names and grouped the following scales with the highest factor loadings:

Factor 1 "Psychophysiological authenticity" included relaxedness of muscles, vocal freedom, naturalness, and ease of vocalizing.

Factor 2 "Psychological authenticity" included randomness, predictability of vocalizing, and correspondence between a sounder's feelings and vocalizations.

Factor 3 "Satisfaction" included satisfaction during and after vocalizing from the sounder's view.

Factor 4 "Vocalization change" included the pitch and intonations.

Factor 5 "Perceived emotional involvement" included loudness, the sounder's feelings, involvement, emotional background, the listener's emotional replies to vocalizations.

Factor 6 "Perceived satisfaction" included the scales of sounder's satisfaction during and after vocalizing from the listener's view.

For further analysis of the vocalization's dynamics and the influence of the research conditions on vocalizations and the sounder's experience, 18 multilinear mixed effect regression models were built. They included 6 models by the meeting number and the group influencing each of the 6 factors, and 12 models by the meeting number in each group for each factor separately. The Benjamini-Hochberg procedure adjusted the p-values for multiple comparisons. Three models were significant (see Tables 3-5).

The "Psychological authenticity" factor was influenced by the group number $(\beta=.306 ; p=.048)$ but not influenced by the meeting number $(\beta=-0.040 ; p=.571)$. The expressive and the impressive groups differed by this factor. The impressive group was \#1 and the expressive group was \#2. This model indicates that the mean scores in "Psychological authenticity" in the expressive group were higher than in the impressive group. The "Satisfaction" factor was also influenced by the group

Table 1

Table 2

Factor model (sounders)

\begin{tabular}{|l|r|r|}
\hline \multicolumn{1}{|c|}{ Indicators } & F1 & F2 \\
\hline SS loadings & 2.00 & 0.63 \\
\hline Proportion Var & 0.29 & 0.09 \\
\hline Cumulative var & 0.29 & 0.37 \\
\hline Relaxedness & 0.71 & 0.00 \\
\hline Constraint & 0.80 & 0.07 \\
\hline Ease & 0.77 & -0.11 \\
\hline Naturalness & 0.43 & 0.18 \\
\hline Predictability & -0.15 & 0.42 \\
\hline Randomness & 0.05 & 0.54 \\
\hline Correspondence & 0.20 & 0.30 \\
\hline
\end{tabular}

Factor model (listeners)

\begin{tabular}{|l|r|r|}
\hline \multicolumn{1}{|c|}{ Indicators } & F1 & F2 \\
\hline SS loadings & 1.61 & 1.08 \\
\hline Proportion Var & 0.23 & 0.15 \\
\hline Cumulative Var & 0.23 & 0.38 \\
\hline Loudness & 0.19 & 0.37 \\
\hline Peach & 0.82 & -0.12 \\
\hline Intonation & 0.77 & 0.11 \\
\hline Feelings & 0.43 & 0.30 \\
\hline Involvement & -0.05 & 0.72 \\
\hline Background & 0.02 & 0.19 \\
\hline Replies & 0.18 & 0.43 \\
\hline
\end{tabular}


The Regression Model with the "Psychological Authenticity" Factor by the Meeting Number and by Group

\begin{tabular}{|l|c|c|c|c|c|}
\hline \multicolumn{1}{|c|}{ Predictor } & Estimate & Std. error & $\boldsymbol{t}$ & $\boldsymbol{p}$ & $\boldsymbol{p}$-adjusted \\
\hline Intercept & 2.946 & .272 & 10.830 & .001 & .001 \\
\hline Meeting number & -0.014 & .020 & -0.665 & .507 & .570 \\
\hline Group & 0.474 & .157 & 3.016 & .005 & .048 \\
\hline
\end{tabular}

Table 4

The Regression Model with the "Satisfaction" Factor by the Meeting Number and by Group

\begin{tabular}{|l|c|c|c|c|c|}
\hline \multicolumn{1}{|c|}{ Predictor } & Estimate & Std. error & $\boldsymbol{t}$ & $\boldsymbol{p}$ & $\boldsymbol{p}$-adjusted \\
\hline Intercept & 3.046 & .282 & 10.820 & .001 & .001 \\
\hline Meeting number & 0.025 & .024 & 1.029 & .305 & .430 \\
\hline Group & 0.519 & .160 & 3.238 & .002 & .048 \\
\hline
\end{tabular}

Table 5

The Regression Model with the "Perceived Satisfaction" Factor by the Meeting Number and by Group

\begin{tabular}{|l|c|c|c|c|c|}
\hline \multicolumn{1}{|c|}{ Predictor } & Estimate & Std. error & $\boldsymbol{t}$ & $\boldsymbol{p}$ & $\boldsymbol{p}$-adjusted \\
\hline Intercept & 3.167 & .235 & 13.487 & .001 & .001 \\
\hline Meeting number & 0.068 & .025 & 2.771 & .006 & .048 \\
\hline Group & 0.277 & .130 & 2.128 & .041 & .157 \\
\hline
\end{tabular}

( $\beta=0.290 ; p=.048)$ but not influenced by the meeting number $(\beta=0.0634 ; p=.430)$. The middle values in this factor were also higher in the expressive than in the impressive group. The "Perceived satisfaction" factor grew with each session $(\beta=0.181$; $p=.048)$ but was not influenced by the group $(\beta=0.164 ; p=.157)$.

The t-test was used to research the differences between groups which the regression models indicated (see Table 6).

The factors "Psychological authenticity" $(p=.001)$ and "Satisfaction" $(p=.001)$ revealed the most significant differences also indicated by the regression models.

The other factors indicating significant differences were "Psychophysiological authenticity" ( $p=.027)$ and "Perceived satisfaction" $(p=.027)$.

\section{Discussion}

The study has several significant limitations. As it was conducted on the basis of person-centered approach and person-centered expressive psychotherapy, the researcher considered the preferences of each participant as the subject of the research. They attended non-equivalent amounts of sessions and chose the groups 
Table 6

T-Test

\begin{tabular}{|l|c|c|c|c|c|c|c|c|}
\hline \multicolumn{1}{|c|}{ Factor } & $\begin{array}{c}\text { Mean } \\
\text { imp. }\end{array}$ & $\begin{array}{c}\text { Mean } \\
\text { exp. }\end{array}$ & $\begin{array}{c}\text { STD } \\
\text { imp. }\end{array}$ & $\begin{array}{c}\text { STD } \\
\text { exp. }\end{array}$ & $\boldsymbol{t}$ & $\boldsymbol{p}$ & $\boldsymbol{p}$-adjusted & Cohen's d \\
\hline $\begin{array}{l}\text { Psychophysiological } \\
\text { authenticity }\end{array}$ & 3.40 & 3.67 & 0.83 & 0.85 & 2.38 & .018 & .027 & 0.317 \\
\hline $\begin{array}{l}\text { Psychological } \\
\text { authenticity }\end{array}$ & 3.38 & 3.85 & 0.85 & 0.64 & 4.58 & .001 & .001 & 0.638 \\
\hline Satisfaction & 3.67 & 4.17 & 1.00 & 0.73 & 4.16 & .001 & .001 & 0.583 \\
\hline Vocalization change & 2.78 & 2.86 & 0.99 & 1.56 & 0.58 & .563 & .562 & 0.076 \\
\hline $\begin{array}{l}\text { Perceived emotional } \\
\text { involvement }\end{array}$ & 3.82 & 3.71 & 0.62 & 0.79 & 1.13 & .262 & .314 & 0.145 \\
\hline $\begin{array}{l}\text { Perceived } \\
\text { satisfaction }\end{array}$ & 3.69 & 3.95 & 0.81 & 0.84 & 2.45 & .015 & .027 & 0.325 \\
\hline
\end{tabular}

they wanted to participate in, resulting in a biased sample. However, it represents people who would choose a similar type of person-centered expressive vocal psychotherapy that has a major input on the perspectives of vocal psychotherapy.

The research was quasi-experimental. The participants may have primary motivations and personality traits making them prone to participate in a specific group. Participants who chose to be in the expressive group were rather interested in selfexploration and self-discovery leading to a more honest and open behavior during the research. Participants who chose the impressive group were prone to conceal their feelings. It was important for the author to investigate the peculiarities of expressive and impressive vocalizations with their characteristics reflected in survey applications for a sounder and for a listener. The task of separating the conditions for vocalizing and the personality traits which influence them was beyond the scope of this research.

Another limitation of this investigation is in the different quantity of sessions for each participant. This was connected to their flexibility when participating in research. In this investigation the researcher concentrated mostly on vocalizations rather than participants. This is why the quantity of each participant's vocalizations lays outside the scope of this study.

The different quantity of sessions with each participant was also related to their personal lives. Only 42 people participated in the research. This limits the opportunity to spread its results to a larger sample. However, this work raises new questions and ideas for new research in the sphere of vocalizations in psychotherapy and develops this field in Russia.

Using the results of this empirical study, the research hypothesis was partially proven. Vocalizations in the expressive group (in the situation of valuing) had significantly higher mean scores by the factors "Psychophysiological authenticity", "Psychological authenticity", "Satisfaction", and "Perceived satisfaction" in comparison to the vocalizations in the impressive group. Significant differences between two groups by "Psychological authenticity" and "Satisfaction" were proven by two methods that allow the opportunity to see a larger authenticity of 
the vocalizations from the expressive group than from the impressive group. All significant factors are involved in the entire concept of authenticity of vocalizations and correspond to the criteria of authentic vocalizations (Zirko \& Orlov, 2017b; Lietaer, 1993) (see Appendix 1). The participants in the expressive group felt more relaxed and free during vocalizing in comparison to the participants from the impressive group. It was also easier for them to vocalize. The feelings they expressed had a greater correspondence to their inner experience than the acted feelings of the participants from the impressive group. Their vocalizations were less random and predictable than vocalizations in the impressive group. The overall satisfaction was significantly higher in the expressive rather than in the impressive group, corresponding to the listener's opinion. The sounder's high satisfaction level indicated their high authenticity (Rogers, 1980). In both groups the scales of the factor "Perceived satisfaction" grew. This is explained by the special peculiarities of each group, which provided similar results. During the research participants from the impressive group felt increasingly confident performing in public and reported this to the researcher and their listeners. They learned to act out different emotions with their voices. This was perceived by their listeners as progress resulting in higher satisfaction. The participants from the expressive group reported feeling more freedom, inner strength, and resources. This also allowed their listener to give higher scores on the factor of "Perceived satisfaction".

Neither the t-test nor regression by group showed any differences between the groups by the factors "Vocalization change" and "Perceived emotional involvement". This indicates that the voices and vocalizations had similar changes in both groups and listeners perceived sounders as similarly involved regardless of the creative task or the process of self-exploration and self-inquiry through their voices. This can be explained because the participants from the expressive group were involved in the process of self-exploration and their voices changed depending on whatever the personal feelings that came out. The participants from the impressive group were involved in the process of doing creative tasks and their voices changed during the task to be more artistic and convey the assigned feelings.

The major factors of authenticity, "Psychophysiological authenticity" and "Psychological authenticity", were significantly higher in the expressive than in the impressive group. They indicated an individual's behavior and corresponded to their feelings and body state, along with what an individual expressed verbally and non-verbally (Uhlig, 2006 et al.).

\section{References}

Austin, D. (2008). The theory and practice of vocal psychotherapy: Songs of the self. London, UK/Philadelphia:, PA Jessica Kingsley Publishers.

Babakina, V. (2016). Kongruentnye I nekongruentnye proyavleniya subjektivnogo opyta klienta (v kontekste praktiki autentichnogo dvizheniya) [Congruent and incongruent manifestations of the client's subjective experience in authentic movement practice] (Master's thesis). Higher School of Economics, Moscow, Russian Federation. (in Russian) 
Baker, F. (2015). Therapeutic songwriting. Developments in theory, methods, and practice. Palgrave Macmillan.

Hiller, J., \& Gardstrom, S. C. (2018). Selection of music experiences in music therapy. Music Therapy Perspectives, 36(1), 79-86.

Kern, P., \& Tague, D. B. (2017). Music therapy practice status and trends worldwide: An international survey study. The Journal of Music Therapy, 54(3), 255-286.

Lewis, G. (2017). "Let your secrets sing out": An auto-ethnographic analysis on how music can afford recovery from child abuse. Voices: A World Forum for Music Therapy, 17(2). doi:10.15845/voices.v17i2.859

Lietaer, G. (1993). Authenticity, congruence and transparency. In D. Brazier (Ed.), Beyond Carl Rogers (pp. 17-46). London, UK: Constable and Company.

Lindblad, K. (2016). Verbal dialogue in music therapy: a hermeneutical analysis of three music therapy sessions. Voices: A World Forum for Music Therapy, 16(1). doi:10.15845/voices.v16i1.842

Linklater, K., Epp, P., \& Snow, W. (1976). Freeing the natural voice. Drama Book Publishers.

Markovich, R., \& Tatsumi, K. (2015). The effects of single-session music therapy interventions in comparison with a cognitive behavioral intervention on mood with adult psychiatric inpatients in an acute-care setting: a quasi-experimental trial. Music Therapy Perspectives, 33(2), 118-127.

Melnikova, M. S., \& Orlov, A. B. (2016). Therapeutic potential of biological feedback: An empirical study. Voprosy Psikhologii, 2, 91-97. (in Russian)

Monti, A., \& Austin, D. (2017). The dialogical self in vocal psychotherapy. Nordic Journal of Music Therapy, 27(2), 158-169. doi:10.1080/08098131.2017.1329227

Orlov, A. B. (2015). Predislovie nauchnogo redaktora [A foreword]. In Tvorcheskaya soyaz'. Istselyayushchaya sila ekspressionykh iskusstv [The creative connection: expressive arts as healing] (pp. 11-15). Moscow: Mann, Ivanov i Ferber. (in Russian)

Pascale, L. M. (2005). Dispelling the myth of the non-singer: Embracing two aesthetics for singing. Philosophy of Music Education Review, 13(2), 165-175.

Petrushin, V. I. (2009). Muzykal'naya psikhologiya [Music psychology]. Moscow: Akademicheskiy prospekt/Gaudeamus. (in Russian)

Rogers, C. R. (1980). A way of being. Boston, MA: Houghton Mifflin.

Rogers, N. (1993). The creative connection: Expressive arts as healing. Science \& Behavior Books.

Stewart, R., \& McAlpin, E. (2016). Prominent elements in songwriting for emotional expression: an integrative review of literature. Music Therapy Perspectives, 34(2), 184-190.

Uhlig, S. (2006). Authentic voices, authentic singing: A multicultural approach to vocal music therapy. Gilsum: Barcelona Publishers.

Vaillancourt, G., Da Costa, D., Han, E. (Yi), \& Lipski, G. (2018). An intergenerational singing group: a community music therapy qualitative research project and graduate student mentoring initiative. Voices: A World Forum for Music Therapy, 18(1). doi:10.15845/voices.v18i1.883

Zirko, A. V., \& Orlov, A. B. (2017, a). Authentic vocalizations: In search of the voice of the inner self. Voprosy Psikhologii, 3, 61-70. (in Russian)

Zirko, A. V., \& Orlov, A. B. (2017, b). Vocal therapy: research perspective. Psikhologicheskie Issledovaniya, 10(53), 3. Retrieved from http://psystudy.ru/index.php/eng/2017v10n53e/1438zirko53e.html (in Russian) 
Subjective Criteria of Four Types of Vocalizations

Appendix 1

\begin{tabular}{|c|c|c|c|c|}
\hline \multirow[b]{2}{*}{ Criteria } & \multicolumn{4}{|c|}{ Types of vocalizations } \\
\hline & $\begin{array}{c}\text { Inauthentic impres- } \\
\text { sive } \\
\text { vocalizations }\end{array}$ & $\begin{array}{c}\text { Inauthentic expres- } \\
\text { sive } \\
\text { vocalizations }\end{array}$ & $\begin{array}{l}\text { Authentic } \\
\text { impressive } \\
\text { vocalizations }\end{array}$ & $\begin{array}{c}\text { Authentic } \\
\text { expressive } \\
\text { vocalizations }\end{array}$ \\
\hline Voice & $\begin{array}{l}\text { Tension; } \\
\text { the intonation } \\
\text { does not change. }\end{array}$ & $\begin{array}{l}\text { Tension; voice } \\
\text { blocks. }\end{array}$ & $\begin{array}{l}\text { Relaxed and free } \\
\text { body and voice. }\end{array}$ & $\begin{array}{l}\text { Relaxed and free } \\
\text { body and voice; } \\
\text { Low pitch. }\end{array}$ \\
\hline Vocalizations & $\begin{array}{l}\text { Vocalizations are } \\
\text { not changing; } \\
\text { a sounder wants } \\
\text { to be accepted by } \\
\text { a listener. }\end{array}$ & $\begin{array}{l}\text { Vocalizations are } \\
\text { changing, but it is } \\
\text { not reflected in } \\
\text { the self-report. }\end{array}$ & $\begin{array}{l}\text { Vocalizations and } \\
\text { the imaginative con- } \\
\text { tents are changing } \\
\text { in order to impress a } \\
\text { listener. }\end{array}$ & $\begin{array}{l}\text { Vocalizations are } \\
\text { changing } \\
\text { through the } \\
\text { experience. }\end{array}$ \\
\hline $\begin{array}{l}\text { Expressing } \\
\text { feelings }\end{array}$ & $\begin{array}{l}\text { A sounder's emo- } \\
\text { tions are not } \\
\text { expressed; } \\
\text { a sounder is } \\
\text { attempting to } \\
\text { impress a listener. }\end{array}$ & $\begin{array}{l}\text { A sounder is con- } \\
\text { centrated on } \\
\text { expressing and liv- } \\
\text { ing through their } \\
\text { experience; } \\
\text { A participant does } \\
\text { not think about } \\
\text { what impression } \\
\text { they make. } \\
\end{array}$ & $\begin{array}{l}\text { The voice communi- } \\
\text { cates imaginative } \\
\text { contents, but not } \\
\text { feelings; The pur- } \\
\text { pose is to impress a } \\
\text { listener. }\end{array}$ & $\begin{array}{l}\text { The voice pre- } \\
\text { cisely expresses } \\
\text { the individual's } \\
\text { experience at the } \\
\text { moment. }\end{array}$ \\
\hline $\begin{array}{l}\text { Limitation or } \\
\text { freedom }\end{array}$ & $\begin{array}{l}\text { A sounder hides } \\
\text { their experience } \\
\text { and deliberately } \\
\text { shows only the } \\
\text { emotions which } \\
\text { can impress people. }\end{array}$ & $\begin{array}{l}\text { Only part of the } \\
\text { experience is } \\
\text { expressed; } \\
\text { The rest of it is } \\
\text { blocked. }\end{array}$ & $\begin{array}{l}\text { Only the feelings } \\
\text { which may impress } \\
\text { a listener are con- } \\
\text { sciously expressed. }\end{array}$ & $\begin{array}{l}\text { The entire expe- } \\
\text { rience is freely } \\
\text { vocalized and is } \\
\text { not blocked. }\end{array}$ \\
\hline $\begin{array}{l}\text { Feelings } \\
\text { during } \\
\text { vocalizing }\end{array}$ & $\begin{array}{l}\text { Tension, unaccep- } \\
\text { tance, anxiety, } \\
\text { irritation, insecu- } \\
\text { rity. }\end{array}$ & $\begin{array}{l}\text { Tension, limita- } \\
\text { tion, incapability, } \\
\text { falsity. }\end{array}$ & Success. & $\begin{array}{l}\text { Feeling right and } \\
\text { precise. }\end{array}$ \\
\hline $\begin{array}{l}\text { Emotional } \\
\text { background }\end{array}$ & $\begin{array}{l}\text { Frustration, } \\
\text { fatigue. }\end{array}$ & Confusion. & $\begin{array}{l}\text { Satisfaction and } \\
\text { pride. }\end{array}$ & Pleasure. \\
\hline Self-image & $\begin{array}{l}\text { The self-image is } \\
\text { unchanging; } \\
\text { If destroyed, a } \\
\text { sounder has nega- } \\
\text { tive feelings. }\end{array}$ & $\begin{array}{l}\text { Self-image may } \\
\text { partly change, but, } \\
\text { the voice mostly } \\
\text { expresses feelings } \\
\text { in a habitual man- } \\
\text { ner. }\end{array}$ & $\begin{array}{l}\text { Self-image is chang- } \\
\text { ing; the voice ran- } \\
\text { domly changes } \\
\text { depending on what- } \\
\text { ever impression } \\
\text { needs to be made. }\end{array}$ & $\begin{array}{l}\text { Self-image is } \\
\text { very dynamic; } \\
\text { The voice } \\
\text { changes depend- } \\
\text { ing on the inner } \\
\text { experience of a } \\
\text { sounder. }\end{array}$ \\
\hline
\end{tabular}




\section{The research applications}

Appendix 2

\section{The introductory application}

Instruction: Write your name or nickname

The application consists of nine 5-point scales and one open question. Please evaluate your vocalizing experience. Mark the multiple-choice on the scale.

1. Do you like the sounds of your voice?

1 - I do not like them.

2 - I rather do not like them

3 - I do not know

4 - I rather like them

5 - I like them

2. In your opinion, is there any connection between the sounds of your voice and your emotions?

$1-$ No, there is no connection

2 - There is rather no connection

3 - I do not know

4 - It rather exists

5 - It exists

3. Are there any situations in your life when you do not use any words but use only the sounds of your voice?

1 - No, never

2 - Very seldom

3 - I do not know

4 - Rather often

5 - All the time

4. How did you usually feel when singing in public?

1 - I felt awful

2 - I had negative feelings

3 - I do not know

4 - I had positive feelings

5 - I felt wonderful

5. In your opinion, can you express your genuine feelings with the sounds of your voice?

1 - No, I never can

2 - Very seldom

3 - I do not know

4 - Rather often

5 - All the time

6. In your opinion, do you conceal your feelings with your voice?

1 - Never

2 - Very seldom

3 - I do not know

4 - Rather often

5 - All the time 
7. In your opinion, can you impress people with your voice?

1 - Never

2 - Very seldom

3 - I do not know

4 - Rather often

5 - Constantly

8. In your opinion, can you be diverted from your actual feelings through your voice?

1 - Never

2 - Very seldom

3 - I do not know

4 - Rather often

5 - All the time

9. In your opinion, does your voice help you better understand your feelings?

1 - Never

2 - Very seldom

3 - I do not know

4 - Very often

5 - All the time

10. Is there anything else about your voice you would like to tell me?

\section{The application for the sounder}

Instruction: Write your name or nickname

The application consists of 95 -point scales. Please evaluate the process and the result of your vocalizations. Mark the multiple-choice on the scale.

1. Evaluate the power of tension in the voice: voice box: diaphragm, body muscles, neck muscles, face muscles, using a 5-point scale. Where in 1 the muscles are tense, and in 5 - the muscles are relaxed.

1. My muscles were very tense

2. My muscles were rather tense

3. My muscles were not tense but not relaxed

4. My muscles were rather relaxed

5. My muscles were relaxed.

2. Evaluate the power of constraint or looseness during sounding using a 5-point scale, where 1 is I felt constraint, 5 - I felt free

1. I felt constraint

2. I felt rather constraint

3. I did not feel constraint and I was not free either

4. I felt rather free

5. I felt free

3. Evaluate the power of difficulty or ease of vocalizing with a 5-point scale, where 1 it was difficult to sound, 5 - it was easy to sound.

1. It was difficult to sound

2. It was rather difficult to sound

3. It was not difficult to sound but it was not easy either

4. It was rather easy to sound 
5. It was easy to sound.

4. Evaluate the power of artificiality or naturalness of vocalizing, where in 1 my vocalizing was artificial, and in 5 my vocalizing was natural.

1. My vocalizing was artificial

2. My vocalizing was rather artificial

3. My vocalizing was not artificial, but was not natural either

4. My vocalizing was rather natural

5. My vocalizing was very natural.

5. Evaluate the power of predictability or unpredictability of vocalizing. 1 is you have always known how you will sound, 5 - you never knew before, which sound will come out.

1. I have always known before, how I will sound

2. More often I have known, how I will sound

3. Sometimes I have known before how I will sound

4. More often I have not known before how I will sound

5. I have never known before, how I will sound.

6. Evaluate the power of randomness or non-randomness of your vocalizing: 1 - vocalizing was random, 5 - vocalizing was not random.

1. My vocalizing was always random

2. My vocalizing was often random

3. My vocalizing was sometimes random

4. My vocalizing was often not random

5. My vocalizing was always not random.

7. Evaluate the correspondents between your feelings and vocalizations, where in 1 the sounds of your voice did not correspond with your feelings at all, and in 5 the sounds of your voice totally corresponded with your feelings.

1. The sounds of my voice did not correspond with my feelings at all

2. The sounds of my voice almost did not correspond with my feelings

3. the sounds of my voice sometimes corresponded with my feelings

4. The sounds of my voice often corresponded with my feelings

5 . The sounds of my voice totally corresponded with my feelings

8. Evaluate the satisfaction level during vocalizing, where in 1 you felt totally dissatisfied during vocalizing, and in 5 you felt totally satisfied during vocalizing.

1. I felt totally dissatisfied during vocalizing

2. I felt dissatisfied during vocalizing

3. I do not know, how much I was satisfied

4. I felt satisfied during vocalizing

5. I felt totally satisfied during vocalizing

9. The satisfaction level after vocalizing, where in 1 you felt totally dissatisfied after vocalizing, and in 5 you felt totally satisfied after vocalizing.

1. I felt totally dissatisfied after vocalizing

2. I felt dissatisfied after vocalizing

3. I do not know, how much I was satisfied

4. I felt satisfied after vocalizing

5. I felt totally satisfied after vocalizing 


\section{The application for the listener}

Instruction: Write your name or nickname

The application consists of 9 5-point scales. Please evaluate the process and the result of vocalizing of the sounder. Mark the multiple-choice on the scale.

1. Evaluate the loudness of vocalizations with the 5-point scale, where 1 is quiet, 5 loud

1. Quiet

2. Rather quiet

3. The medium level of loudness

4. Rather loud

5. Loud

2. The dynamics of pitch

1. The pitch does not change

2. The pitch changes very insignificantly

3. The pitch changes rather significantly

4. The pitch changes significantly

5 . The pitch changes very significantly

3. The dynamics of intonations

1. The intonations do not change

2. The intonations change insignificantly

3. The intonations change rather significantly

4. The intonations change significantly

5. The intonations change very significantly

4. Feelings in vocalizations

1. There are no feelings

2. There are very few feelings

3. There are not a lot, but not few feelings

4. There are rather a lot of feelings

5. There are a lot of feelings and they are various

5. Involvement of the sounder in the process of vocalizing

1. The sounder is not involved in the process

2 . The sounder is weakly involved in the process

3. The sounder is involved in the process on the medium level

4. The sounder is strongly involved in the process

5 . The sounder is totally involved in the process

6. Negative or positive emotional background during vocalizing

1. Negative emotional background

2. Emotional background is rather negative

3. Neutral emotional background

4. Emotional background is rather positive

5. Positive emotional background

7. Emotional replies from the listener to the vocalizations

1. The vocalizations did not affect me

2 . The vocalizations weakly affected me

3 . The vocalizations affected me on the medium level

4. The vocalizations affected me rather strongly 
5. The vocalizations totally and strongly affected me

8. The satisfaction level during vocalizing

1. The sounder felt totally unsatisfied during vocalizing

2. The sounder felt unsatisfied during vocalizing

3. I do not know, how much the sounder was satisfied

4. The sounder felt satisfied during vocalizing

5 . The sounder felt totally satisfied during vocalizing

9. The satisfaction level of the sounder after vocalizing

1. The sounder felt totally unsatisfied after vocalizing

2. The sounder felt unsatisfied after vocalizing

3. I do not know, how much the sounder was satisfied

4. The sounder felt satisfied after vocalizing

5 . The sounder felt totally satisfied after vocalizing

Alena. V. Zirko - PhD in Psychology.

Research Area: vocal music psychotherapy, person-centered approach, vocal practices in psychotherapy, person-centered expressive psychotherapy.

E-mail: alena@mlbox.ru

\section{Типы вокализаций в самовыражении и самоисследовании}

\section{А.В. Зирко \\ Резюме}

Вокализации рассматриваются как невербальное использование звуков голоса в самовыражении и самоисследовании. Цель исследования состоит в изучении специфики процессов самовыражения и самоисследования человека с помощью вокализаций в условиях принятия и оценки. Мы предположили, что при условии принятия и ценения вокализации будут обладать более высокими показателями аутентичности, чем при условии оценки. Были выделены две группы участников: группа экспрессии, в которой соблюдались условия безоценочного принятия, и группа импрессии, в которой моделировались условия оценки. Участники группы экспрессии выражали свои переживания с помощью звуков голоса, а участники группы импрессии выполняли исследовательские задания, направленные на развитие выразительности своего голоса. После вокализирования участники обеих групп заполняли исследовательские анкеты, в которых изучались состояние тела и голоса звучащего, чувства звучащего и слушающего в ходе исследования. Показатели, полученные с помощью этих анкет, были объединены в шесть факторов: «Психоиииологическая аутентичность», «Психологическая аутентичность», «Удовлетворенность», «Изменение вокализаций», «Воспринимаемая эмоциональная включенность» и «Воспринимаемая удовлетворенность». Для изучения динамики вокализаций и влияния условий исследования на вокализации были построены модели множественной регрессии. С помощью t-критерия Стьюдента группы участников сравнивались между собой. Значимые различия 
наблюдались по факторам «Психофизиологическая аутентичность», «Психологическая аутентичность», «Удовлетворенность» и «Воспринимаемая удовлетворенность». Значения по всем факторам были выше в группе экспрессии, чем в группе импрессии. В обеих группах возрастали показатели по фактору «Воспринимаемая удовлетворенность».

Ключевые слова: вокалопсихотерапия, вокализации, аутентичность, неаутентичность, экспрессивность, импрессивность.

Зирко Алена Владиславовна - кандидат психологических наук.

Сфера научных интересов: вокальные и голосовые практики в психотерапии, человекоцентрированный подход, музыкотерапия, вокалотерапия, человекоцентрированная экспрессивная психотерапия.

Контакты: alena@mlbox.ru 